subcutaneous method of sewing the skin. He had also observed that skin sutures not infrequently suppurate, even in wounds sewed by the niost careful surgeons in this country and abroad.

8. One or two small, sliort gauze plugs are used as wound drains.

The immediate result in all the cases reported was good. Three of the patients were children, two adults. Sufficient time has not yet elapsed to test the ultinate results.-Johns Hopkins Hosp. Bull. Dec.

IV. Fecal Fistula following Hernia. By Prof. Czervr (Heidelberg). In the course of a paper read before the Sixty Second Congress of German Naturalists and Physicians, at Heidelberg, i889, upon resection of the intestins, Czerny refers to 6 cases of operation for fecal fistula following the occurence of hernia. In general the fistula was cir. cumscribed elliptically by an incision. the incision lengthened and the bowel loosened from its attachnents. Turning the edges of the mucous membrane and uniting the parts by means of successive layers of sutures sufficed in only two instances. In the balance of the cases circular resection of intestine preceded the suturing; otherwise stenosis of the bowel at this point was to be found. In one case in which nu. merous fistulous tracks permeated the vicinity, the abdominal cavity was opened above louparts, the bowel loosened and sutured at the point where it was joined by the fistula. Five cases of fistula conmunicating with the small intestine, and one with the transverse colon, were resected with the best results. One case, that of a female exhausted by phthisis, induced by want of nourishment, died of collapse; healing by primary union took place in the remaining five.

Kœnig, of Gattingen, in the course of the discussion which followed Czerny's paper, related 3 cases in which, after enlarging the opening, he drew the bowel forward and closed the opening leading thereto, by transverse sutures, thus avoiding resection of the bowel.-Centlb. $f$. Chirg., No. 51, 1889 .

G. R. FowLEK (Brooklyn).

EXTREMITIES.

1. Treatment of Aneurisms of the Limbs. Frexch Surgical CoNgress,(Oct., I889). When this subject came up for consideration, of 
nine prominent surgeons who took part in the diseussion, six were in favor of ligating the artery above and below the diseased point and extirpating the sae.

For arterio-venous aneurisns they all agreed that ligation of the vessels eombined with extirpation of the mass was the only method of treatment.

Verneuil was of the opinion that non-operative methods should be used when the patient was above jo years of age, for at this time of life the mortality after operation was exeedingly high, and that at this time non-operative methods gave brilliant results. Verneuil spoke against extipating the sac in ordinary aneurisms, as simple ligature of the artery gave good results. - Reaue de Chirurgie, No. II, is89.

F. C. Ilussos (New York).

\section{GENITO-URINARY ORGANS.}

I. Surgical Exploration of the Kidneys. By DR. J. RECAMIter (Paris). The author reviews the different methods of exploration for purposes of diagnosis of the surgieal affections of the kidneys. Ex. ploratory puneture is spoken of disparagingly, while pereussion and palpation are endorsed unqualifiedly. The bimanual (Guyon's bal. lottenent and Glenord's "nephroleptic") method, with the patient in the dorsal position, it is claimed, pernits of a very thorough examination of the organ, revealing increase in volume. mobility and conditions of undue sensibility. The most important point in the author's thesis relates to the immediate exanination of the organs by means of an exploratory ineision, this being, as a rule, made in the lumbar region, save in those eases in which it is necessary to demonstrnte the existenee of both organs, as well as where the location of the disease eannot be previously determined; hence the abdominal ineision is preferred. Early exploration by incision is recommended partieularly in the following: st, In those eases in which the diagnosis rests between nephro-lithiasis and eommeneing tumor, as well as where the charaeter of a suppuration in the pelvis of the kidney remains in doubt. $2 d$, In eases of anuria with obstruction of the ureters. $3^{\text {d, For the }}$ purpose of demonstrating the existenee and eondition of the other 